\title{
Blame Avoidance in Comparative Perspective: Reactivity, Staged Retreat and Efficacy
}

\author{
Christopher Hood, All Souls College, University of Oxford
}

Will Jennings, University of Southampton

Paul Copeland, Queen Mary, University of London

Forthcoming in Public Administration.

Acknowledgements: the authors wish to thank the ESRC Centre for Analysis of Risk and Regulation for providing financial support to this research. An earlier version of this paper was presented at the London School of Economics and Political Science. Thanks to Shaun Bevan for his advice on earlier versions of this article. 


\begin{abstract}
Building on blame-avoidance analysis, this paper develops a method to assess the reactivity, sequencing and efficacy of defensive responses by officeholders facing a crisis of personal blame, analysing cases drawn from four advanced democracies. It tests the hypotheses that officeholders: react by positive action rather than nonengagement when blame levels are high; respond in a 'staged retreat' sequence; and can reduce the level of blame they face from one day to another through choice of presentational strategies. The paper applies event history analysis to test the sequencing hypothesis and time series cross-sectional models to test the reactivity and efficacy hypotheses. The analysis shows that officeholders tend to respond actively when blame levels are high, that to some extent their responses tend to follow a staged retreat pattern, and their interventions have a systematic effect on the next day's media blame level only if they take the form of personal statements.
\end{abstract}

Keywords: Blame avoidance, blame, crisis, staged retreat, event history analysis 


\section{Blame Avoidance in Political Crises and Scandals: Is There Order Beneath the Apparent Chaos?}

This paper aims to contribute to a new generation of research on blame avoidance. It challenges the commonly-held view (as put forward by Barker 1994, for example) that the course of events in political crises and scandals is typically unpredictable, chaotic and unmanageable, with events running out of control and no underlying regularities. That view is reflected in a range of sometimes contradictory proverbs about political scandals. For example it is claimed that active media management is the key to success (as in the oft-quoted maxim of former Nixon aide Roger Stone, 'Admit nothing, deny everything, launch counterattack' (Labash 2007)) or alternatively that initial non-response is the best strategy given short media attention-spans (Hood 2011: 58-9). Others suggest that 'the cover-up is worse than the crime', or that efforts at spin are ultimately self-defeating (Kurtz 1998).

The analysis of blame avoidance in politics is beginning to allow us to bring more systematic evidence to bear on such claims. Although ideas about the handling of blame in politics stretch back to Machiavelli and beyond, the modern analysis of blame avoidance is barely 30 years old, starting with Kent Weaver's (1986) seminal contribution. It brought together observations about negativity bias (Lau 1985) and political behaviour (Fiorina 1981), to develop a perspective that cut across several political science subfields such as voting and political behaviour, public administration and public policy (see also Hood 2002; 2011). Weaver's basic claim was that politicians tend to give greater weight to potential blame (for losses) than credit (for gains), consistent with insights from prospect theory (Kahneman and Tversky 1979).

There have since been some theoretical explorations of blame avoidance, but 
most empirical studies have been qualitative, particularly in the welfare state literature (e.g. Pierson 1994; Lindbom 2007). There has been some quantitative analysis using survey data, notably to determine how political and institutional context affects blame of government for economic performance (e.g. Powell and Whitten 1993; Anderson 1995) and how ministerial resignations absorb blame and raise government popularity (e.g. Dewan and Dowding 1995); observational and experimental studies of negativity bias (e.g. Dixon et al. 2013; Olsen 2015: 469-79); and some other experimental work on the handling of blame (notably by McGraw 1990 and 1991 and Sulitzeanu-Kenan 2006). Today, data available through digitally-searchable media make quantitative analyses of blame episodes and media negativity more practicable than in the past (Hood et al. 2009; Hood and Dixon 2010; Resodihardjo et al. 2015). That approach is developed here. Up to now, most research on blame avoidance has been based on single-country studies. Our paper aims to enhance the generalizability of the analysis of blame avoidance by observing regularities across countries.

We argue that contrary to the common idea that the politics of crisis and scandal is marked by chaotic contingency, there may be some systematic order in underlying behaviour and dynamics. We compare how heads of government, in four different democracies, behaved when they faced media blame over their personal judgements or behaviour. Further, we assess the effectiveness of their efforts to manage blame. Our data are drawn from the U.S., U.K., Ireland and Canada, and involve scandals over personal conduct by four heads of government, namely a U.S. President (Bill Clinton), an Irish Taoiseach (Bertie Ahern), a U.K. Prime Minister (Tony Blair), and a Canadian Prime Minister (Jean Chrétien). Taking negative press 
coverage as a proxy for blame, ${ }^{1}$ we develop a method for analysis and comparison of the behaviour of officeholders facing blame, analysing the day-to-day level of blame those individuals faced in the press over periods ranging from a month to two years, and the day-to-day actions they took in response.

The paper is organised as follows. First, it outlines three general hypotheses about presentational strategies of blame avoidance by senior public officeholders (i.e. attempts to deflect, avoid or mitigate blame through public rhetoric, argument or news management). Second, it briefly describes the four episodes of scandals relating to personal or political misconduct by heads of government, as mentioned above, and explains how media blame and officeholders' presentational responses were measured. Third, it uses this data, in time series cross-sectional and event history format, to analyse the link between blame levels and the incidence of officeholder responses, the underlying structure of the sequencing of responses and the impact of categories of response on the level of blame in the media. The paper concludes by discussing the findings and their significance for comparative analysis of blame avoidance and future possible applications of the method.

\section{Sequencing, Reactivity and Efficacy of Presentational Blame Avoidance}

\section{Behaviour: Three Hypotheses}

Theories of blame avoidance are concerned with how holders of public or political office seek to avoid blame for their decisions or actions. Blame $\left(B_{t}\right)$ is

\footnotetext{
${ }^{1}$ Our underlying assumption is either that: (a) levels of blame in the press are a good proxy for latent public blame; or (b) even if (a) does not apply, public officeholders have sufficiently good reasons to fear high levels of blame in the press to wish to avoid or minimize it.
} 
conventionally defined as a combination of perceived avoidable harm $\left(\mathrm{PAH}_{\mathrm{t}}\right)$ and perceived responsibility $\left(\mathrm{PR}_{\mathrm{t}}\right)$ at any given point in time (Sulitzeanu-Kenan and Hood 2005; Hood 2011: 6). The developing literature on blame avoidance, mentioned earlier, identifies various ways for organizations and officeholders to try to reduce or avoid blame (for summaries, see Bovens et al. 1999: 127-128; Hood 2002; 2011; Sulitzeanu-Kenan and Hood 2005). ${ }^{2}$ Figure 1 depicts the sequence of choices faced by officeholders over how to respond to actual or expected criticism that are explored in this paper. For the sort of scandal considered here, involving allegations of personal misconduct or misjudgement by senior political officeholders, presentational strategies of blame avoidance seem to be the most appropriate focus for two reasons. One is that direct attempts to manage media coverage will be more readily applicable in responding to claims of personal misconduct or individual misjudgement by top officeholders, compared to alternative approaches to blame avoidance (such as delegation of responsibility or the use of standard decision protocols). The other is that in such cases officeholders have little option but to engage in reactive crisis management after a scandal has erupted, obviating the need for pre-emptive strategies for limiting perceived responsibility redundant (Hood 2011: 148-50).

\section{FIGURE 1 HERE}

Existing studies offer some limited insights on a number of key aspects of blame avoidance behaviour, including (i) the effect of different levels of blame $\left(\mathrm{B}_{\mathrm{t} 0}\right)$ on decisions of officeholders whether to take an active or a passive stance; (ii) the temporal sequencing of presentational strategies; and (iii) the effectiveness of different strategies in affecting the relationship between blame on one day $\left(\mathrm{B}_{\mathrm{t} 0}\right)$ and

\footnotetext{
${ }^{2}$ This approach necessarily puts factors such as individual personality and emotion into the background when modelling senior officeholders' behaviour.
} 
the next $\left(\mathrm{B}_{\mathrm{t} 1}\right)$. Drawing on earlier studies, we accordingly present three general hypotheses about blame avoidance behaviour that we later test.

(a) The reactivity hypothesis

The reactivity hypothesis refers to stage 2 in Figure 1, and suggests that when levels of blame are high, officeholders will be more likely to take an active stance (AS) than remaining passive (PS).

$\mathrm{H}_{1}$ : Higher levels of blame will be associated with a greater likelihood of presentational responses by officeholders.

That is, higher levels of blame will be likely to lead to active attempts to reduce or remove it than 'do nothing' or 'no comment' responses. The hypothesis here, following the tenor of the active media management approach, is that modern media and politics create pressures for the pursuit of strategies of active denial and counterattack (as advocated by spin doctors such as Roger Stone and Alastair Campbell) when blame levels are high. Still, it could be that there is some level of blame at which any given officeholder or organization's credibility is so low that any active response is likely to produce a worse outcome than a passive stance, by exacerbating the blame level.

(b) The sequencing hypothesis

Our second hypothesis concerns the sequencing of actions in the active stance branches of presentational strategies of blame avoidance, depicted in stages 3 and 4 in Figure 1. This derives from earlier work (Hood et al. 2009) building on the analysis of Schütz (1996: 116ff). (For alternative frameworks encompassing a wider array of 
strategic choices, see Bovens et al. 1999; Branström and Kuipers 2003; Hearit 2006; Hood 2011.)

Problem denial $(P D)$ responses operate on the perceived avoidable harm element of blame, involving denials, justifications or excuses (McGraw 1990; 1991) intended to show there is no significant avoidable harm, loss or risk. If that strategy is successful, at stage 3, the issue of blame cannot arise and the question of responsibility is therefore redundant (see for example Schütz 1996: 122-3). Alternatively, presentational strategies can focus on the responsibility element of blame, focusing on responsibility denial $(R D)$ in the next branch of the decision tree, stage 4 in Figure 1. Responsibility denial comprises ways of persuading potential blamers that the officeholder or organization concerned was not responsible for any avoidable loss or harm that could have occurred. When problem denial is not a tenable presentational approach for some reason, officeholders must choose problem admission $(P A)$. If they do so, they then face a choice between the strategy of problem admission combined with responsibility denial $(P A+R D)$ and of problem admission combined with responsibility admission $(P A+R A)$. The former involves admitting the existence of harm or loss combined with denial of responsibility (for example by asserting that no-one is responsible, that others are responsible or that responsibility has yet to be determined). The latter involves an admission of both problem and responsibility.

The sequencing hypothesis to be tested here, implicit in the logic of blame avoidance, is that officeholders normally accept responsibility $(P A+R A)$ only if problem denial $(P D)$ and/or problem admission combined with responsibility denial $(P A+R D)$ are untenable. 
$\mathrm{H}_{2}$ : officeholders will tend only to admit problems $(P A)$ after problem denial $(P D)$ is no longer tenable, and only accept responsibility after problem denial $(P D)$ and responsibility denial $(P A+R D)$ strategies have become untenable.

(c) The efficacy hypothesis

Our third hypothesis concerns the effectiveness of presentational strategies in changing the relationship between blame at one point in time $\left(\mathrm{B}_{\mathrm{t} 0}\right)$ and another $\left(\mathrm{B}_{\mathrm{t} 1}\right)$. . This issue is important because there are conflicting proverbs about the merits of active media management versus non-response (as mentioned earlier), and because, even though the term 'blame avoidance' is commonly used both to denote the activity of seeking to avoid blame and the outcome of blame avoided, it is vital to distinguish the two in analysis (Sulitzeanu-Kenan and Hood 2005). Of course the problem of making causal evaluations in the face of numerous intervening variables must be acknowledged (see Bovens et al. 1999: 146), but the method used here enables us for the first time in a comparative study to establish the causal effects of framing as a presentational strategy in a way that controls for statistical noise and the inherent dynamics of events. We therefore test the hypothesis that officeholders' presentational responses, in the form of problem denial $(P D)$, responsibility denial $(P A+R D)$ and responsibility admission $(P A+R A)$, are effective in making a difference to the level of blame in future time periods and we look more specifically at the effects of the different sub-types of presentational approach, to be described in more detail later.

$\mathrm{H}_{3}$ : presentational strategies of blame avoidance reduce the level of blame in subsequent time periods.

\section{Episodes, Cases and Data}


We analyse here 106 cases of officeholder responses to blame in the media drawn from four episodes of political scandal which are summarized in Table 1. Each episode involved allegations of serious personal misconduct, misjudgement or abuse of office by heads of government, raising issues whose handling would be crucial to the career or reputation of any such officeholder. Each of the scandals was arguably among the most serious threats to the political career of each of the respective heads of government during their term in office - where substantial blame and political consequences were present. So these scandals represent a key test of how officeholders behave when faced with blame in contemporary democracies, given the small number of such scandals available. The purpose of the comparison, as explained earlier, is to establish whether there are common patterns of behaviour during blame firestorms across different leaders and political systems.

All four officeholders concerned were male, white, centrist or centre-left heads of government in wealthy liberal democracies. The allegations of misconduct they faced consisted of improper sexual behaviour linked to perjury in one case, and improper acceptance of funds for personal or party use in the other three - all issues with sufficient potential to damage reputations or end careers to make blameavoidance a serious concern for the officeholders concerned. The scandals broke at different points in the officeholders' careers - at the start, indeed during the 'honeymoon,' of one officeholder's tenure as head of government (Tony Blair), but much later in the term of two others (Bill Clinton and Bertie Ahern, who had been in office some five or nine years respectively when the scandals considered here began to break), and continued well after the individual concerned had left office in the other case (Jean Chrétien). The political systems over which these officeholders presided varied in their scale and institutional form (two unitary, two federal, three 
parliamentary, one presidential), and the institutional processes through which the issues were handled were different too. With the exception of the Blair episode, each scandal involved some form of formal forensic inquiry, with the Clinton investigation led by a special prosecutor (Kenneth Starr) and the Ahern and Chrétien cases subject to judicial inquiries (the Mahon Tribunal and Gomery Commission respectively). What interests us is whether there are underlying commonalities in the activity, sequencing and efficacy of presentational blame avoidance behaviour by these officeholders that cut across such differences.

The Clinton-Lewinsky scandal is by far the best-known of these episodes, as a classic example of a political scandal in a highly charged political and media climate. It started with leaks to the press of an affair, uncovered by another investigation by Independent Counsel Kenneth Starr, between President Clinton and a White House intern, Monica Lewinsky. At first, Clinton made a famously worded denial (see Tiersma 2004; Kuntz 1998, The Starr Report: 356), but later, after testifying before a grand jury Clinton admitted on national television that he had had an inappropriate relationship with Lewinsky. These revelations led the House of Representatives Judiciary Committee to initiate an impeachment inquiry, leading to Clinton's impeachment by the House on grounds of perjury and Clinton's subsequent acquittal after a 21-day trial in the Senate.

A notable feature of this episode is Clinton's retreat from an original 'privacy' stance over the Lewinsky affair to one of confessional contrition (see Lee and Barton 2003). Despite polls indicating widespread belief that Clinton had lied over the affair and salacious details continuing to emerge from the inquiry (Harris 1999), Clinton's approval rating rose to a peak during the impeachment proceedings, and Zaller (1998, p. 182) argues that the scandal demonstrated "the importance of political substance, as 
against media hype, in American politics." Polls suggested that many respondents distinguished private from public conduct and viewed the investigations as partisan attacks (Kagay 1999), a perception stressed by the White House public opinion apparatus (see Heith 2000).

The Bernie Ecclestone affair struck Tony Blair's Labour Government in its honeymoon period just five months after it came to power criticising the 'Tory sleaze' of the previous government and declaring that it had to be seen to be 'purer than pure'. The scandal was reported to have led Prime Minister Tony Blair to fear it would finish his career (Oliver and Oakeshott 2008). On November 5, 1997, the government announced that Formula 1 motor racing would be exempt from a ban on tobacco advertising. Just a week later, the Labour Party admitted that the head of the F1 organization (Bernie Ecclestone) had given Labour $£ 1$ million earlier in the year. In opposition, Labour had assembled a formidable spin machine focused on communications and pre-buttal, that owed much to the Clinton model (see Gould 1999; Campbell 2007). The diaries of government communications chief Alistair Campbell (2007, p. 257-62) reveal debate over the handling of the issue within Number 10, with Blair favouring ignoring the media outcry and hoping it would go away (that is, following a passive response as depicted in Figure 1), and Campbell arguing for an active response. As media criticism continued, Campbell's approach won out and on November 16th, Blair appeared on national television to apologise for the way the F1 exemption had been handled, conceding that mistakes had been made, but denying impropriety and offering the famous personal defence 'I think most people who have dealt with me think I'm a pretty straight sort of guy, and I am' (BBC, 'On The Record'). While the Ecclestone affair took some of the shine off the new 
government, it had no long-term impact on its popularity, and Blair was able to draw a line under the scandal.

The scandal involving Irish Taoiseach Bertie Ahern involved allegations of corrupt payments to politicians, in particular relating to planning permits and land rezoning, that were revealed by the Mahon Tribunal, Ireland's longest-running public inquiry. Like Tony Blair, Ahern had entered government with a reputation for probity, contrasting with that of his predecessor, Charles Haughey, who had made Fianna Fail known as 'the party of the brown envelope' (McKittrick 2007, p.30). The Tribunal began a detailed investigation into Ahern's finances in 2004, when it transpired that Ahern did not operate any personal bank accounts for some seven years and kept large sums in cash in his office which he claimed to have saved from his salary (Mahon Tribunal 2012, p.1286), and the scandal broke in September 2006, with allegations of Ahern receiving payments from a property developer. Ahern admitted he had been given IR£39,000 in 1993 and 1994 but said he had considered those payments as a loan from friends to finance his marital separation, claiming he had 'broken no codes ethical, tax, legal or otherwise'. (Gifts from overseas and domestic loans were not subject to tax in Ireland at that time.) While Ahern's Fianna Fail emerged as the largest party in the April 2007 Irish election and formed a coalition government with the Greens, the allegations persisted. In September 2007, Ahern told the Mahon inquiry, 'I have done no wrong... I never took a bribe.' Facing negative publicity, Ahern finally repaid IR£39,000 of what he claimed to have been loans after the Tribunal had identified them and in a carefully-worded statement to the Irish parliament, he said, 'The bewilderment caused to the public about recent revelations has been deeply upsetting for me and others near and dear to me. To them, to the Irish people and to this house, I offer my apologies.' When further questions arose over the 
provenance of some IR $£ 50,000$ he had paid into his bank account, Ahern claimed the money had been saved between 1987 and 1994 when he had no active bank account (Mahon Tribunal 2012, p.1435). There were further allegations over Ahern's finances and his tax liabilities as the Mahon Tribunal continued its investigation, with several cases in which the Tribunal rejected Ahern's explanation of the source of unexplained bank lodgements (Mahon Tribunal 2012, pp.1470-1). In testimony to the Mahon Tribunal in April 2008 Ahern claimed a payment to his former partner had been direct from his salary, but this claim was contradicted by his former secretary who said the payment had been in British pounds. After this episode, Ahern announced his intention to resign in May 2008.

The Chrétien episode, relating to corrupt payments as part of a federal program differs in two important respects from the others. First, the head of government at the centre of the scandal, former Prime Minister Jean Chrétien, was no longer in office when the report of the Canadian Auditor-General was published in January 2004, revealing that contracts of up to $\mathrm{C} \$ 100$ million in a federal sponsorship program had been given to Liberal Party-friendly advertising firms and Crown corporations for minimal work. Second, the scandal caused a sharp fall in support for the governing Liberal Party, which lost power in the 2006 Canadian general election. But the Gomery Commission's revelations of corruption in payment to advertising firms did affect the Liberal Party while it was still in government, partly because it called into questions the activities of Paul Martin, Chrétien's successor as Prime Minister, who had been Finance Minister at the time in question and was a longstanding rival to Chrétien. However, Martin claimed no knowledge of the programme while he was Minister for Finance, saying that it had been run exclusively from the Prime Minister's Office, so allegations focused on Chrétien and Martin was cleared. Justice 
Gomery was also later ruled by a federal court to have shown 'unacceptable bias' against Chrétien.

\section{TABLE 1}

Data

To compile cases of officeholder responses to media blame from these four episodes, searches were conducted using the Dow Jones Factiva database (http://factiva.com/factiva/) to collect data on stories from four or five national newspapers for each episode. The newspapers were selected to measure the tone of national media coverage during each scandal and were selected with the aim of providing a representative sample of media content that was not skewed towards a particular region, partisan stance or editorial style (see Online Appendix Table A1). Stories related to each episode were identified through a systematic search between the defined start and end dates of the scandal, using search terms known to provide comprehensive and representative coverage of the episode (as identified through exploratory searches of the Factiva database). Search data were filtered to include only articles in which the scandal was the direct subject, rather than those articles that were either indirectly related or in which it was referred to but not the main subject.

To measure the level of media blame falling on the heads of government, we identified all stories appearing in the sample of newspapers during the scandal and graded each of the stories on a given day according to a 'blame barometer' to measure the negativity of media content. Officeholder blame was scored on a scale between 0 and 5 , where 0 referred to news articles that were wholly factual or neutral and 5 referred to articles where officeholders were subject to the highest level of blame and criticism. Those scores for individual articles were, in turn, aggregated to form a daily 
score for all articles. ${ }^{3}$ The blame barometer, developed by Hood et al. (2009, p. 718), is shown in Online Appendix Table A2. In the absence of a well-developed scoring convention for blame, distinct from general tone of media content, this represents an attempt to measure a spectrum that runs from factual reports and a benign political environment to circumstances in which even typically reliable supporters, such as partisans or 'payroll voters,' have turned hostile and are calling for officeholders' resignations. $^{4}$

The blame firestorms identified with this method are plotted in Figure 2 and the summary statistics reported in Table 2, bringing out similarities and differences among the episodes. Perhaps most striking is the short duration of the Blair episode, which, as mentioned earlier, occurred during a political honeymoon period and failed to gain traction - dissipating within a month. In the Ahern and Chretien episodes, initial spikes in media blame were followed by extended periods of low level noise as the scandal unfolded over an extended period, but with sudden and large upturns in media blame at critical points in the scandal. These blame spikes were more frequent

\footnotetext{
${ }^{3}$ To limit coder subjectivity and inconsistency, articles were identified and filtered by one of the authors. In an initial coding exercise, all authors coded a sample of 30 articles of each episode to ensure the coding framework was applied consistently. Thereafter articles were periodically crossed-checked at random and the authors consulted one another on articles that were hard to classify. These procedures indicated a rate of coder reliability in excess of 90 per cent.

${ }^{4}$ An alternative to coding the level of media blame, would be to identify news stories containing new information relating to the scandal, allowing analysis to test whether the emergence of new facts, revelations or critics influence officeholders' responses.
} 
in the Ahern episode, but in all the episodes there was a final flare-up before the heat eventually died out. The intermittent pattern of these media firestorms is consistent with the view of agenda-setting processes as subject to dramatic, large 'punctuations' in political and media attention (Jones and Baumgartner 2005).

\section{FIGURE 2}

\section{TABLE 2}

\section{$H_{1}$ : The Reactivity Hypothesis: Officeholder Reactivity and Blame Avoidance}

To test the first hypothesis, that blame will tend to push officeholders into an active stance rather than passive responses in presentational strategies of blame avoidance, we explore whether there was a systematic difference across the four blame episodes in the incidence of any type of officeholder response (of which there were 106 cases in total) on days on which there was a relatively lower or higher level of media blame. To do so, we used a time series cross-sectional (panel) autoregressive distributed lag (ADL) model to capture the general autoregressive character of blame across all the episodes. ${ }^{5}$ This has the advantage of examining the general relationship between the level of blame on a given day and presence of a blame avoidance response, across all episodes, controlling for the effect of past levels of blame, rather than an episode-specific relationship. We can therefore examine the degree to which the reactivity hypothesis holds in general.

The results presented in Table 3 confirm that the blame dynamics observed are autoregressive $\left(0.436^{* * *}\right)$, indicating that yesterday's level of blame is predictive of future values of blame. This amounts, on average, to $44 \%$ of a given day's volume of

\footnotetext{
${ }^{5}$ The data is organised in the form case $(i) *$ day $(t)$, with the ADL model represented
} as:

BLAME $_{\mathrm{it}}=\alpha_{0}+\alpha_{\mathrm{it}-1}$ BLAME $_{\mathrm{it}-1}+\alpha_{\mathrm{it}}$ RESPONSE $_{\mathrm{it}}$. 
negative media coverage being carried forward into the next day's newspapers. More importantly, the level of blame was significantly higher on days on which there was an officeholder response $(8.932 * * *)$. Since the mean level of blame across the four episodes is 1.97 , this means the media climate was more than four times more negative on days where officeholders offered a response. This provides considerable support for the reactivity hypothesis $\left(\mathrm{H}_{1}\right)$, suggesting officeholders were indeed responding to the signal of higher than normal blame.

\section{TABLE 3}

$\mathrm{H}_{2}$ : The Sequencing Hypothesis: An Event History Analysis of Staged Retreat in Officeholder Responses

Our second hypothesis posits that officeholders normally accept responsibility $(P A+R A)$ only if problem denial $(P D)$ and/or responsibility denial $(P A+R D)$ are untenable strategies. This suggests a temporal dimension in officeholder responses during political crises or scandals, running from problem denial $(P D)$ to problem admission but responsibility denial $(P A+R D)$ to responsibility admission $(P A+R A)$. We tested this hypothesis in two ways.

One used event history analysis (e.g. Box-Steffensmeier and Jones 1997), to test how long officeholders persisted with a particular presentational strategy (such as problem denial) before moving to a different one (such as responsibility denial). The structure of our dependent variable for this hypothesis was binary; indicating whether or not an officeholder offered a particular response on a given day. Using this approach, after the scandal commenced (defined in each case by the trigger event reported in Table 1, which indicates the initial starting point of $t=1$ ), the officeholder could at any point offer a presentational response aimed at the management of blame, 
drawing upon one of the three categories of response described earlier. Because multiple presentational responses were offered during each of the scandals, this is modelled as a repeated events survival process. That means that an event (i.e. response) can occur for the same individual multiple times. So once an officeholder has offered a particular category of presentational response (on one or multiple successive days in a row), ${ }^{6}$ the process is reset and the survival process begins again (the clock is reset to $t=1$ ) and further responses are possible. This means that the total $N$ of events is 85 , as the number of discrete officeholder responses drawing on one of the strategies. (This data structure is illustrated in Online Appendix, Table A3.)

\section{Test 1: Kaplan-Meier Survival Estimates}

Figure 3 offers a graphical illustration of non-parametric Kaplan-Meier survival estimates, showing the duration before officeholders offered a presentational response in each of the three categories of problem denial, responsibility denial and responsibility admission, beginning at $\mathrm{t}=0$ with $100 \%$ of observations in a state waiting for a response to be offered. Tellingly, concerning the pace at which such media firestorms unfold, for problem denial by $t=10$ the proportion of non-responses from officeholders was less than 50\%. After ten days of each repeated event process, less than half were yet to register a response. After 31 days, this percentage dropped to $25 \%$. Throughout the scandals, officeholders regularly employed problem denial strategies, almost always sooner than other stances. Figure 3 shows that the adoption of problem admission combined with responsibility denial $(P A+R D)$ tended to take longer than problem denial, consistent with the sequencing hypothesis. After 31 days, around $40 \%$ of cases were still to register a response (well above the $25 \%$ for problem

\footnotetext{
${ }^{6}$ This treats officeholder responses in the same category on consecutive days as the same event.
} 
denial). Indeed, by around 75 days when problem denial responses had long been exhausted by officeholders, a quarter of problem admission responses had not yet been called upon.

Similarly, the uptake of responsibility admission $(P A+R A)$ was slower during the early days of each survival process, with $50 \%$ still to occur after 31 days, considerably longer than the other possible responses. This indicates that officeholder responses without responsibility admission tended to occur later than problem denial or problem admission and responsibility denial. However, after around 40 days (and around $60 \%$ of responses) this clean temporal sequencing of officeholder responses ceases to apply. Instead, responsibility admission responses are exhausted well before all the responsibility denial responses are adopted. This might suggest that officeholders in such scandals do not last long without admitting responsibility in some form. It also points to the fact that the evidence to support the sequencing hypothesis is only partial.

These Kaplan-Meier survival estimates show how quickly some of these blame firestorms unfolded as well as their cyclical, iterative character, since there is overlap in the survival rate of officeholder responses. But they also show that in the Ahern, Clinton and Chretien scandals there were extended periods when officeholders offered no responses at all, whether due to the absence of media blame or due to a strategy of 'no comment'.

\section{FIGURE 3 HERE}

Test 2: Parametric Accelerated Failure Time Models of Blame Management Responses

We further tested the second hypothesis by determining the accelerated failure time (AFT) of presentational strategies of blame management. Using this method, the 
survival rate is estimated as a function of a baseline survival function and an acceleration factor composed of covariates that stretch or shrink the survival curve along the time axis. ${ }^{7}$ This makes it possible to determine whether a covariate such as the level of media blame or government popularity increases or decreases the expected duration before an officeholder adopts a particular category of presentational response as part of the staged retreat sequence. ${ }^{8}$ We can additionally control for whether problem denial $(P D)$ and problem admission and responsibility denial $(P A+R D)$ response have previously been offered during the scandal timeline. This provides a test of the interdependence of officeholder responses, implied by the staged retreat hypothesis.

We estimate a parametric AFT model combining data from the four episodes. Pooling the data is consistent with our theoretical expectation of a common structure of the sequencing of officeholder responses, and consequently the underlying survival rate, across time and across political systems. This enables us to determine whether there is a general pattern in the duration of presentational responses (since variance across the four episodes will only serve to weaken the results). Further, our

${ }^{7}$ This represents the survival rate $\mathrm{S}(t)$ as a function of a baseline survival function, $\mathrm{S}_{0}(t)$ and $\varphi$, an acceleration factor that is a function of specified covariates $\left(\mathrm{x}_{1}, \mathrm{x}_{2} \ldots\right.$ $\mathrm{x}_{\mathrm{k}}$ ) for a defined distribution, $p$. This can be represented as:

$$
\begin{aligned}
& \mathrm{S}(t)=\mathrm{S}_{0}(\varphi t) \\
& \varphi=p\left\{\left(\mathrm{~b}_{1} \mathrm{x}_{1}+\mathrm{b}_{2} \mathrm{x}_{2}+\ldots+\mathrm{b}_{k} \mathrm{x}_{k}\right)\right\}
\end{aligned}
$$

${ }^{8}$ In this analysis we omit other explanatory factors, such as the state of the economy, which could potentially affect the pattern of staged retreat, though it is not obvious why it should do so for these personal-conduct issues. Note that regression parameter estimates from AFT models are robust to omitted covariates (Keiding et al. 1997). 
sequencing hypothesis $\left(\mathrm{H}_{2}\right)$ is consistent with a Weibull distribution, where hazard rates either increase or decrease monotonically over time. We would therefore expect the survival rate of problem denial $(P D)$ responses to decrease most rapidly over time, and the survival rates of problem admission $(P A+R D)$ and responsibility admission $(R A)$ to decrease more slowly, since the latter can be expected to be increasingly used once other responses become untenable. ${ }^{9}$

Table 4 shows the results for each of the categories of officeholder response. The AFT rate is a constant that changes the predicted event time. Any AFT rate less than 1 represents a decrease in survival time, and any rate greater than 1 represents an increase in survival time. For example, the AFT rate for the blame level is 0.91 in the problem denial $(P D)$ model, reported in the first column, indicating that higher blame levels are associated with a 9\% decrease in survival time. This is consistent with our first hypothesis $\left(\mathrm{H}_{1}\right)$ that there is a greater likelihood of officeholder responses at higher blame levels. This finding is significant, since the confidence intervals indicate the value of the AFT rate is less than 1. The AFT rate for the blame level is lower for both the responsibility denial $(P A+R D)$ and responsibility admission $(P A+R A)$ models, reported in the second and third columns respectively, indicating that the effect of blame on the time it takes for an officeholder to offer a response is greater for these categories on days with a high blame level, compared to problem denial $(P D)$ responses. These results are confirmed in the shape of the AFT functions in Figure 4, plotted for the base (zero), first quartile, median and third quartile of the blame level. This indicates that for each type of presentational strategy, the survival

\footnotetext{
${ }^{9}$ The accelerated failure time model can be expressed as:

$\log \lambda_{\mathrm{i}}(t)=\beta^{*}{ }_{0}+\beta^{*}{ }_{1} x_{i 1}+\ldots+\beta^{*}{ }_{k} x_{i k}+\varepsilon$ where $\beta \varphi / \sigma$ for all $\varphi, \alpha=1 / \sigma-1$ and $\varepsilon$ are i.i.d.
} 
rate is lower at higher blame levels. Further, at lower blame levels, the survival rate is lowest for problem denial $(P D)$ and is lower for responsibility denial $(P A+R D)$ than for responsibility admission $(P A+R A)$, consistent with the staged retreat pattern postulated by the sequencing hypothesis $\left(\mathrm{H}_{3}\right)$.

The results also show that the prior occurrence of a problem denial $(P D)$ response does not significantly influence the propensity of officeholders to adopt either of the other response categories (i.e. $P A+R D$ or $P A+R A$ ). In contrast, prior occurrence of a problem admission and responsibility denial $(P A+R D)$ response does significantly increase the likelihood of an officeholder offering an admission of responsibility $(P A+R A)$. The AFT rate for this is equal to 0.15 , meaning the prior response is associated with an $85 \%$ decrease in survival time. This again offers partial support to the sequencing hypothesis.

We included government popularity as an additional covariate to consider whether this influences the likelihood of officeholder responses. ${ }^{10}$ Interestingly, the results suggest that this does not influence problem denial, but increases the survival rate for problem admission $\left(1.108^{*}\right)$, thereby reducing the likelihood of this sort of response, but decreases the survival rate for responsibility admission $\left(0.957^{*}\right)$. In sum, from this analysis popular officeholders seem less likely to admit problems, but more likely to admit responsibility.

\section{TABLE 4 HERE}

The distribution parameter, Weibull's $p$, is significantly different from 1 for problem denial $(P D)$ responses (as indicated by the $95 \%$ confidence intervals) and so is

\footnotetext{
${ }^{10}$ Our measure of government popularity in the U.S. is presidential approval, and voting intention for the governing party for the U.K., Canada and Ireland (data from Jennings and Wlezien 2015; Green and Jennings n.d.).
} 
significantly different from the exponential distribution results. ${ }^{11}$ This finding suggests that the overall survival rate declines over time, whereas the survival rate does not exhibit significant change over time for responsibility denial $(P A+R D)$ and responsibility admission $(P A+R A)$ responses. This finding is consistent with the 'staged retreat' pattern suggested in our second hypothesis. Moreover, when the blame level is highest (illustrated in Figure 4 at the third quartile), there is a notable decrease in the survival time of problem admission $(P A+R D)$ and responsibility admission $(P A+R A)$, suggesting the pattern of staged retreat is partly determined by the level of blame as well as by time.

\section{FIGURE 4 HERE}

$H_{3}$ : The Efficacy Hypothesis: Estimating the Effectiveness of Presentational Blame Management

We tested the third hypothesis, about the efficacy of presentational strategies of blame avoidance, by exploring the effect of officeholders' responses on one day on the level of blame appearing in the press on subsequent days. Did those responses appear to act as water or gasoline on the flames of recrimination, or have no impact? To explore that, we again used a time series cross-sectional ADL model to estimate the efficacy of presentational strategies of blame avoidance across the four episodes,

${ }^{11}$ We also tested this using the Cox (proportional hazards) parameterization instead of the Weibull distribution and this produces similar, and consistent, results. Indeed, the AIC is superior for two out of three models using the Weibull parameterization (with the exception of the $P A+R D$ model, where the difference between the AICs is small, and the shape of the curve of the survival rate for that model resembles that plotted in Figure 4). 
building on previous studies (notably Hood et al. 2009). This method estimates the effect of officeholder responses, controlling for the general autoregressive character of blame across all the episodes. It thus tests whether there is a significant effect of adopting a particular response on the level of blame on the next day and subsequent days, compared to days when no response is offered, controlling for the effect of past levels of blame. This approach is well-suited for determining the effects that presentational strategies adopted by officeholders on a particular day have on the following day's blame level, independent of other effects that arise from relationships between blame at different points in time.

Since we are concerned here with day-to-day blame management, we specified the models in terms of 'pulse interventions' (the temporary impact of an officeholders' presentational strategy of blame avoidance), ${ }^{12}$ but we included lagged values in the analysis to allow for the possibility that the effectiveness of responses in dampening the media firestorm might not be instantaneous but spread over several days. We first considered the question of whether it is better for officeholders, when faced with blame, to do something or nothing at all. ${ }^{13}$ The second column of Table 5 presents the results of this analysis, suggesting the efficacy of presentational blame avoidance strategies were unimpressive in these cases. The level of blame was not significantly different on the day following a response (0.816). On the second day

12 This indicates that an intervention is temporary at time $t_{j}$, such that $X_{j}=\left\{\begin{array}{l}0 \text { if } t \neq t_{j} \\ 1 \text { if } t=t_{j}\end{array}\right.$

${ }^{13}$ The data is again organised in the form case $(i) *$ day $(t)$, with an ADL model represented as:

BLAME $_{\mathrm{it}}=\alpha_{0}+\alpha_{\mathrm{it}-1}$ BLAME $_{\mathrm{it}-1}+\alpha_{\mathrm{it}-1} \mathrm{RESPONSE}_{\mathrm{it}-1}+\alpha_{\mathrm{it}-2} \mathrm{RESPONSE}_{\mathrm{it}-2}$ 
following a response the level of blame was, in fact, significantly higher, not lower $\left(0.896^{*}\right)$.

In light of these findings, one might wonder whether there is much hope for the efficacy hypothesis $\left(\mathrm{H}_{3}\right)$. But we were able to test a variant of the efficacy hypothesis, by examining whether 'personal' responses by officeholders were more effective in bringing about a change in media blame - such as through a directly attributed quote or public statement - than responses made by spin doctors, press secretaries or official spokespeople. Notably, this provides broad support to the efficacy hypothesis. The effect of personal officeholder responses is negative and significant both on the next day $\left(-1.752^{* *}\right)$ and the second day $\left(-1.866^{* *}\right)$ following a response. There appears to be a difference, then, between the effectiveness of the procedural or 'holding' responses by media relations people compared with direct personal declarations of officeholders

\section{TABLE 5 HERE}

Finally, we tested all three types of presentational strategy described earlier, using the same general ADL model, to compare the relative efficacy of the different approaches to blame avoidance. The results presented in the first column of Table 6 again suggest the efficacy of presentational blame avoidance strategies were unimpressive. The blame level was in fact significantly higher on the day following a problem denial response $\left(1.204^{*}\right)$ and on the second day following a responsibility denial response $(3.059 * * *)$. These attempts to manage blame appear to have served to fuel the media feeding frenzy. Further, responsibility acceptance did not have a significant effect in dampening the flames of the media firestorm.

When testing personal responses of officeholders (see the second column of Table 6), there is more evidence to support this variant of the efficacy hypothesis. 
Personal attempts at blame avoidance resulted in a significant decrease in the blame level both for problem denial $(P D)$ responses on the second day $\left(-2.706^{*}\right)$ and for responsibility admission $(P A+R A)$ responses on the first $(-6.054 * * *)$ and second days $(-3.943 * * *)$. While problem denials appeared to have some effect in initially dampening the flames, the personal acceptance of responsibility seems to be the most effective strategy of blame avoidance, at least as far as quietening the media firestorm is concerned. These results are consistent with findings in previous work (Hood et al. 2009, p. 711).

\section{TABLE 6 HERE}

\section{Conclusion}

There is a long-held view that the course of events in political crises and scandals is unpredictable, stochastic and unmanageable. This comparative analysis of blame avoidance behaviour and outcomes across four democracies shows there were indeed common patterns of response despite considerable variations in the scandals, in terms of the length of the episode, the extent to which investigations attracted party-political conflict, and whether or not they led to electoral defeat or resignation by the relevant officeholders.

Despite such variations, this analysis reveals common patterns of reactivity, staged retreat and efficacy across all four episodes, indicating underlying similarities in the dynamics both of officeholder responses and their interaction with media blame. This analysis upholds at least a variant of all three hypotheses tested here. First, there is unmistakable evidence of reactivity, in that officeholder responses tended to occur at higher levels of negative media attention. Both the time series 
cross-sectional analysis and the event history analysis suggest there was a higher likelihood of officeholder responses when blame was high.

Second, there is at least partial evidence for the 'staged retreat' sequencing hypothesis. As we saw, the survival rates for the problem denial $(P D)$ and problem admission combined with responsibility denial $(P A+R D)$ categories of response declined over time, whereas that for responsibility admission $(P A+R A)$ did not. This indicates a shift towards this latter stance once earlier strategies were exhausted. The sequencing of blame responses also seemed to be mediated by blame levels. Higher blame levels were apparently associated with the occurrence of later categories in the staged retreat in both the survival curves and accelerated failure rates. When blame levels were at their highest the survival rate of responsibility admission $(P A+R A)$ dropped dramatically, suggesting that while the staged retreat is a general pattern, there is nothing like a high level of negative attention to force officeholders into highcontrition responses.

The third, efficacy, hypothesis - that it is better to do something than to do nothing, in terms of short-term blame reduction - is only upheld when officeholders' responses consisted of direct personal statements, rather than in off the record briefings or statements from official spokespersons or third parties. This effect applies particularly to those presentational responses of the responsibility admission $(P A+R A)$ variety, which did appear to dampen the flames of media blame in these cases. It could of course be that a temporary fuelling of the media flames might act as a firebreak and dampen media blame in the longer-term, a possibility we cannot entirely discount. Otherwise, officeholders' blame-management interventions did not appear to have much effect on the next day's level of blame in the press. As with so much else in politics, activity is not the same as achievement. 
We do not want to claim that the 106 cases analyzed here, drawn from four episodes of officeholder attempts to grapple with blame arising from perceived failures, omissions and misconduct, are necessarily typical of all blame avoidance arenas. For instance, in these episodes the combination of problem admission and responsibility denial was not used as frequently as problem admission combined with responsibility admission, probably because of the unavoidably personal nature of the issues in question. This contrasts with cases where institutional structures allow for more complex blame games, following what Schattschneider (1960) terms the 'expansion of conflict'. Clearly, the analysis of different types of blame episodes in future research might well enable the identification of systematic differences across political and media contexts. ${ }^{14}$ This analysis does support the important claim, however, that there are commonalities in blame dynamics and officeholder responses, even in very different political systems, and is consistent with some of the basic propositions associated with the blame-avoidance approach in political science. Of course we are far from being able to predict the duration and outcome of any given blame episodes and we do not deny that the individual personality characteristics of officeholders may help to shape responses, but the kind of analysis pursued here can help develop more systematic understanding both of general patterns of officeholder response to blame and of the efficacy of presentational tactics in assuaging media, political and public criticism.

\footnotetext{
${ }^{14}$ As studies of blame avoidance draw on increasing number of cases, sampled over longer time periods, the addition of covariates to modelling strategies should enable the testing of variation according to political and/or institutional context.
} 


\section{$\underline{\text { References }}$}

Barker, Anthony. (1994). 'The Upturned Stone; Political Scandals and Their Investigative Processes in Twenty Democracies.' Crime, Law and Social Change 21: 337-373.

Bovens, Mark, Paul 't Hart, Sander Dekker and Gerdien Verheuvel. (1999). 'The Politics of Blame Avoidance: Defensive Tactics in a Dutch Crime-Fighting Fiasco.' In Helmut K. Anheier (ed.), When Things Go Wrong. London: Sage, pp. $123-48$.

Box-Steffensmeier, Janet M. and Brad Jones. (1997). 'Time is of the Essence: Event History Models in Political Science.' American Journal of Political Science 41(4): 1414-1461.

Brändström, Annika, and Sanneke Kuipers. (2003). 'From Normal Incidents to Political Crises: Understanding the Selective Politicization of Policy Failures.' Government and Opposition 38(3): 279-305.

Dixon, Ruth, Christiane Arndt. Manuel Mullers, Jarmo Vakkuri, Kristiina EngblomPelkkala, and Christopher Hood. (2013) 'A Lever for Improvement or a Magnet for Blame? Press and Political Responses to International Educational Rankings in Four EU Countries.' Public Administration 91(2): 484-505.

Dewan, Torun, and Keith Dowding (2005). 'The Corrective Effect of Ministerial Resignations on Government Popularity.' American Journal of Political Science 49(1): 46-56.

Fiorina, Morris P. (1981). Retrospective Voting in American National Elections. New Haven: Yale University Press.

Gould, Philip. (1999). The Unfinished Revolution: How the Modernisers Saved the Labour Party. London: Abacus. 
Green, Jane, and Will Jennings. (n.d.). The Politics of Competence: Concepts, Causes and Consequences. Cambridge: Cambridge University Press. Forthcoming.

Hearit, Keith M. (2006). Crisis Management by Apology: Corporate Response to Allegations of Wrongdoing. Mahwah, NJ: Lawrence Erlbaum Associates.

Heith, Diane J. (2000). 'Polling for a Defense: The White House Public Opinion Apparatus and the Clinton Impeachment.' Presidential Studies Quarterly 30(4): 783-790.

Hood, Christopher. (2002). The Risk Game and the Blame Game. Government and Opposition 37(1): 15-37.

Hood, Christopher. (2011). The Blame Game: Spin, Bureaucracy, and SelfPreservation in Government. Princeton: Princeton University Press

Hood, Christopher, Will Jennings, Brian Hogwood, Ruth Dixon and Craig Beeston. (2009). 'Testing Times: Exploring Staged Responses and the Impact of Blame Management Strategies in two Exam Fiasco cases.' European Journal of Political Research 48(6): 695-722.

Jennings, Will, and Christopher Wlezien. (2015). 'The Timeline of Elections: A Comparative Perspective.' American Journal of Political Science. doi: 10.1111/ajps.12189.

Jones, Bryan, and Frank Baumgartner. (2005). The Politics of Attention: How Government Prioritizes Problems. Chicago: University of Chicago Press. Kagay, Michael. (1999). 'Presidential Address: Public Opinion and Polling During Presidential Scandal and Impeachment.' Public Opinion Quarterly 63(3): 449463. 
Keiding, Niels, Andersen, Per K., and Klein, John P. (1997). 'The Role of Frailty Models and Accelerated Failure Time Models in Describing Heterogeneity Due to Omitted Covariates.' Statistics in Medicine 16(1-3): 215-224.

Kurtz, Howard. (1998). Spin Cycle: Inside the Clinton Propaganda Machine. New York: Free Press.

Kuntz, Phil (Ed.). (1998). The Evidence: The Starr Report. New York: Pocket Books. Lau, Richard R. (1985). 'Two explanations for Negativity Effects in Political Behaviour.' American Journal of Political Science 29(1): 119-138.

Labash, Matt (2007). 'Roger Stone, Political Animal, 'Above all, attack, attack, attack — never defend.'. The Weekly Standard, 5 November 2007.

Lee, Ronald, and Matthew H. Barton. (2003). Clinton's Rhetoric of Contrition. In Robert E. Denton and Rachel L. Holloway (eds.), Images, Scandal and Communication Strategies of the Clinton Presidency. Westport, Connecticut: Praeger, pp. 219-46.

Lindbom, Anders (2007). 'Obfuscating Retrenchment: Swedish Welfare Policy in the 1990s.' Journal of Public Policy 27(2): 129-50.

McGraw, Kathleen M. (1990). 'Avoiding blame: An experimental investigation of political excuses and justifications.' British Journal of Political Science 20(1): 119-132.

McGraw, Kathleen M. (1991). 'Managing Blame: An Experimental Test of the Effects of Political Accounts.' American Political Science Review 85(4): 11331157.

McKittrick, David. (2007). 'Ahern still defiant over cash-in-case allegations.' The Independent, September 14, 2007. 
http://www.independent.co.uk/news/world/europe/ahern-still-defiant-overcashincase-allegations-402311.html

Mahon Tribunal. (2012). Final Report of the Tribunal of Inquiry into Certain Planning Matters and Payments, chaired by His Honour Judge Alan P Mahon $S C$.

http://www.oireachtas.ie/parliament/media/committees/archivedcommittees/cnr anda/The-Final-Report-Mahon.pdf

Oliver, Jonathan, and Isabel Oakeshott. (2008). 'Secret papers reveal Tony Blair's F1 tobacco deal.’ The Sunday Times, October 12, 2008. http://www.timesonline.co.uk/tol/news/politics/article4926737.ece

Olsen, Asmus Leth. (2015). 'Citizen (Dis)satisfaction: An Experimental Equivalence Framing Study.' Public Administration Review 75(3): 469-78.

Resodihardjo, Sandra L., Brendan J. Carroll, Carola J.A. Van Eijk, and Sanne Maris. (2015). 'Why Traditional Responses to Blame Games Fail: The Importance of Context, Rituals, and Sub-Blame Games in the Face of Raves Gone Wrong.' Public Administration. doi: 10.1111/padm.12202.

Schattschneider, Elmer E. (1960). The Semisovereign People. New York: Holt, Reinhardt and Winston.

Schütz, Astrid (1996) 'Selbstdarstellung in der Defensive - Reaktionen in politischen Skandalen.' Chapter 3 in Lothar Laux and Astrid Schütz (eds.), “Wir, die wir gut sind”: Die Selbstdarstellung von Politikern zwischen Glorifizierung und Glaubwürdigkeit, München, Deutscher Taschenbuch Verlag.

Sulitzeanu-Kenan, Raanan. (2006). 'If They Get it Right: An Experimental Test of the Effects of UK Public Inquiries' Appointment and Reports.' Public Administration 84(3): 623-653 
Sulitzeanu-Kenan, Raanan, and Christopher Hood. (2005). 'Blame Avoidance with Adjectives? Motivation, Opportunity, Activity and Outcome.' Paper presented at ECPR Joint Sessions, Granada, Spain.

Tiersma, Peter M. (2004). 'Did Clinton Lie? Defining “Sexual Relations”.' ChicagoKent Law Review 79: 927-958.

van Thijn, Ed (e.a.). (2002). De Sorry-democratie: Recente politieke affaires en de ministeriële verantwoordelijkheid. Amsterdam: Van Gennep.

Weaver, R. Kent. (1986). 'The Politics of Blame Avoidance.' Journal of Public Policy 6(4): 371-98.

Zaller, John R. (1998). 'Monica Lewinsky's contribution to political science.' PS: Political Science and Politics 33: 182-189. 


\section{TABLES \& FIGURES}

Figure 1. Playing the Blame Game: Four Sets of Choices

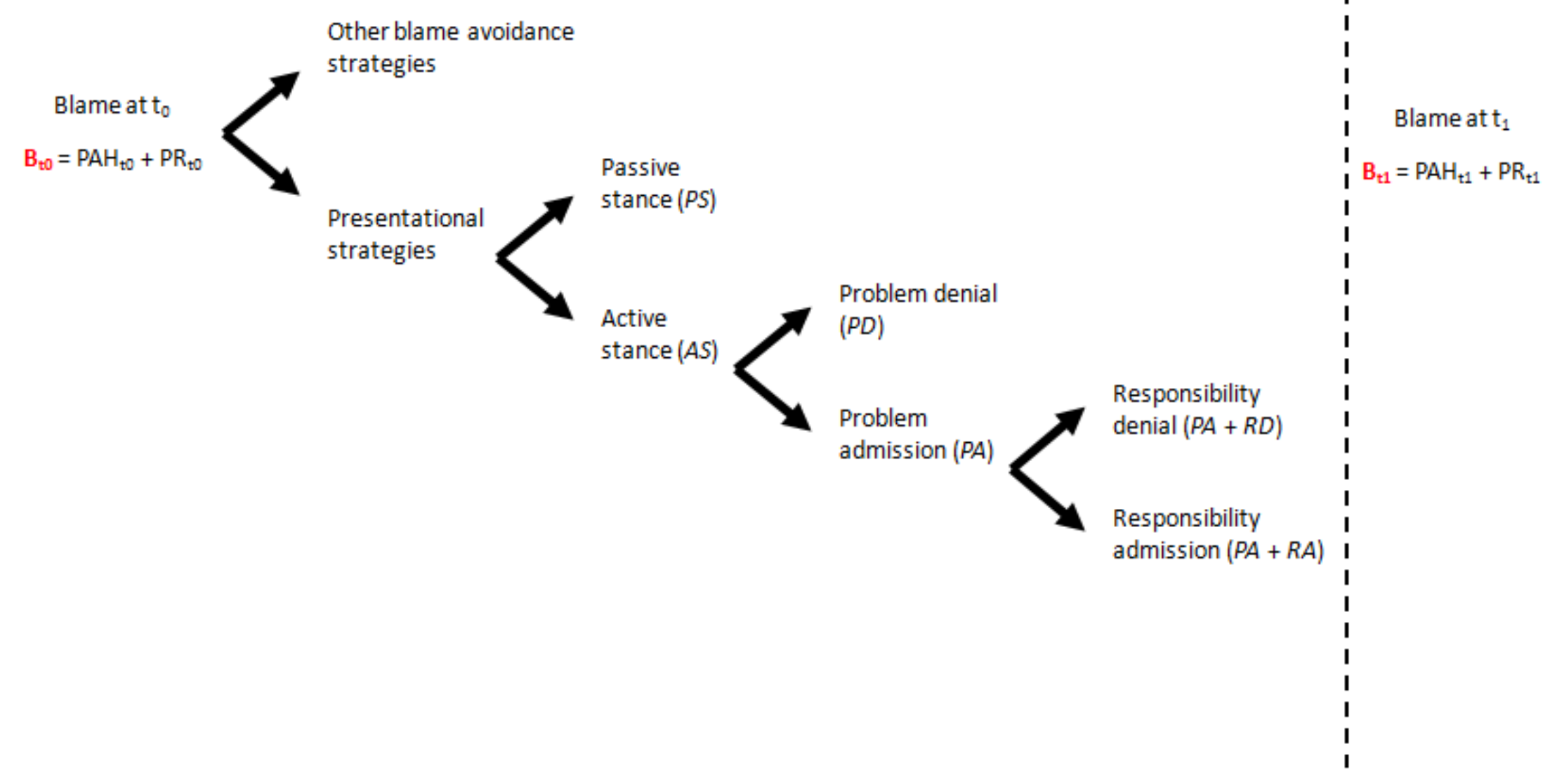


Figure 2. Blame Timelines in the Ahern, Blair, Chretien and Clinton Scandals
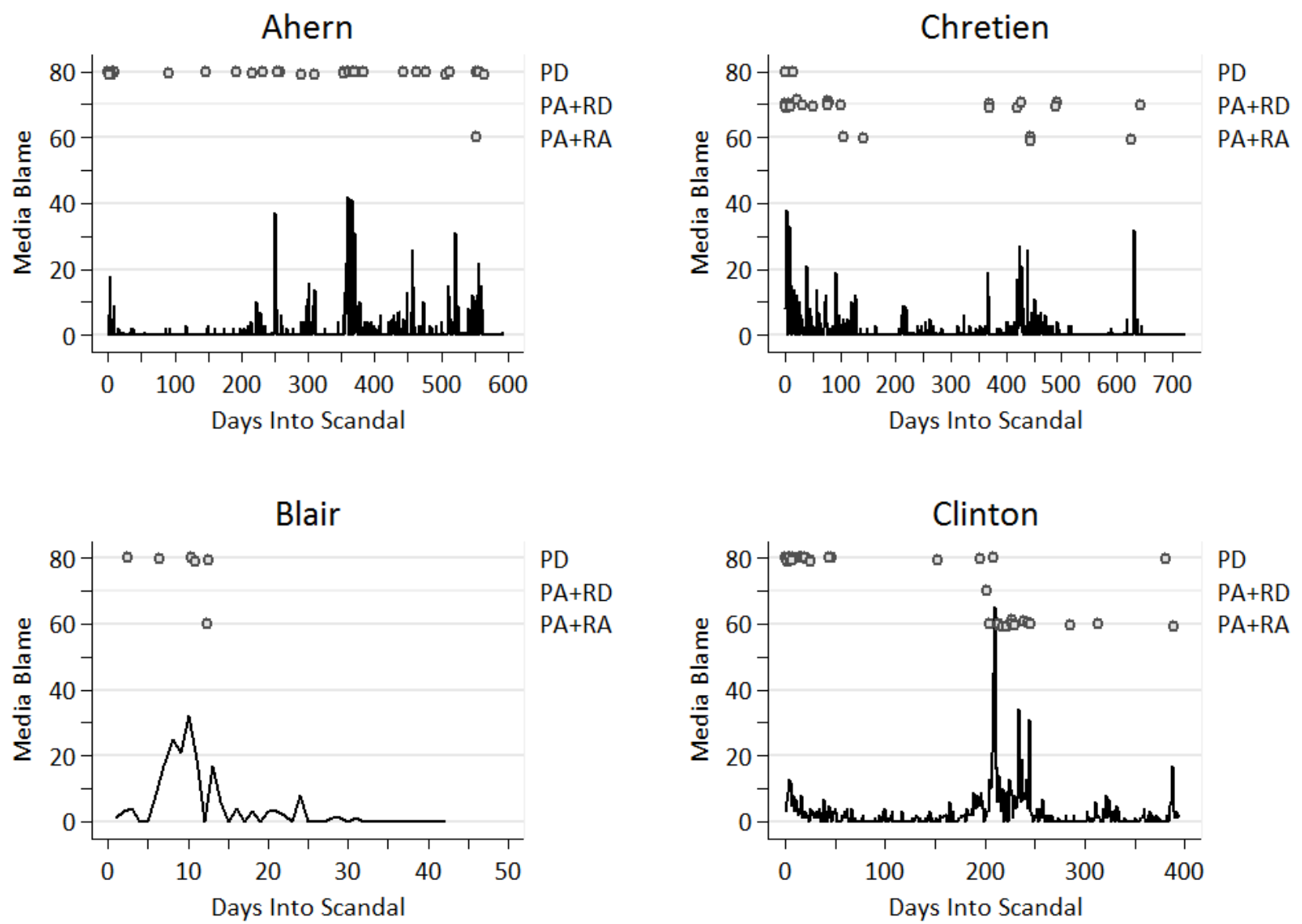
Figure 3. Kaplan-Meier Survival Estimate of Officeholder Responses

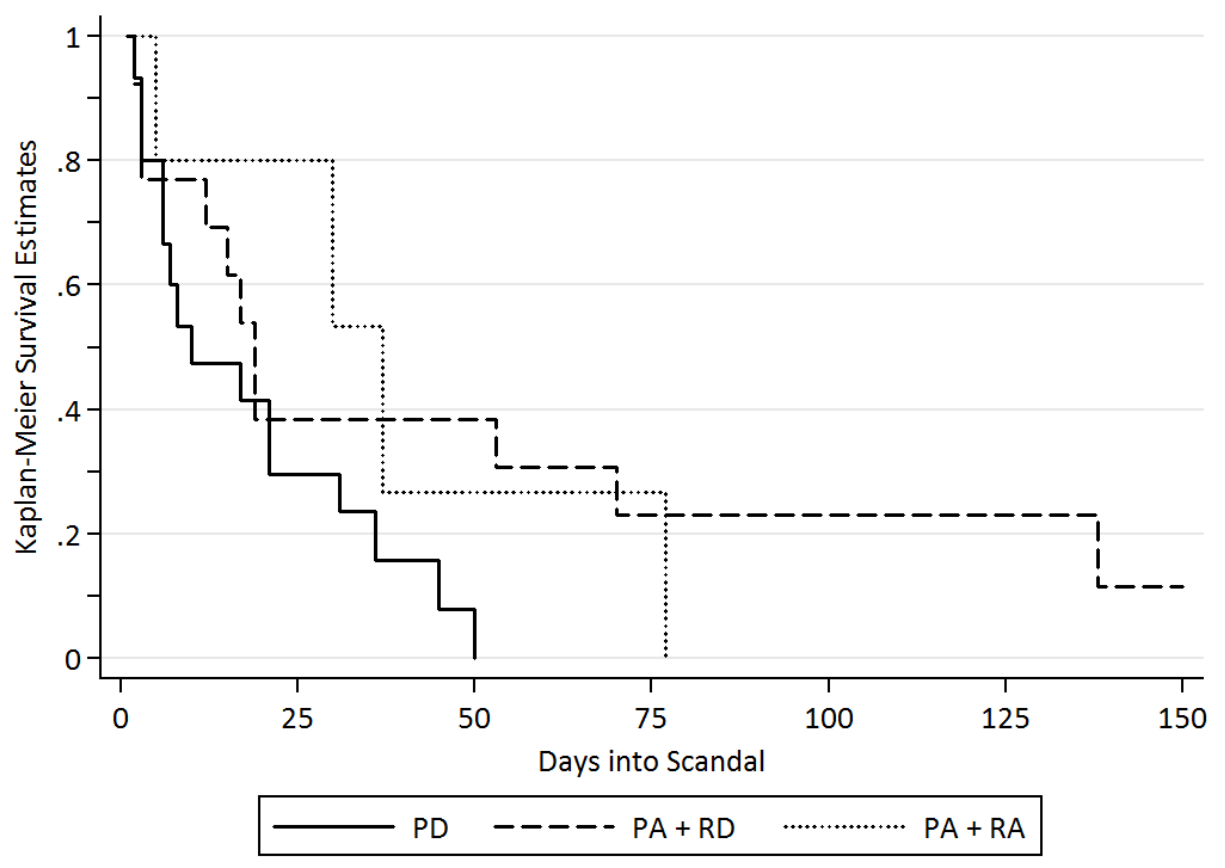


Figure 4. Survival Rate of Officeholder Responses
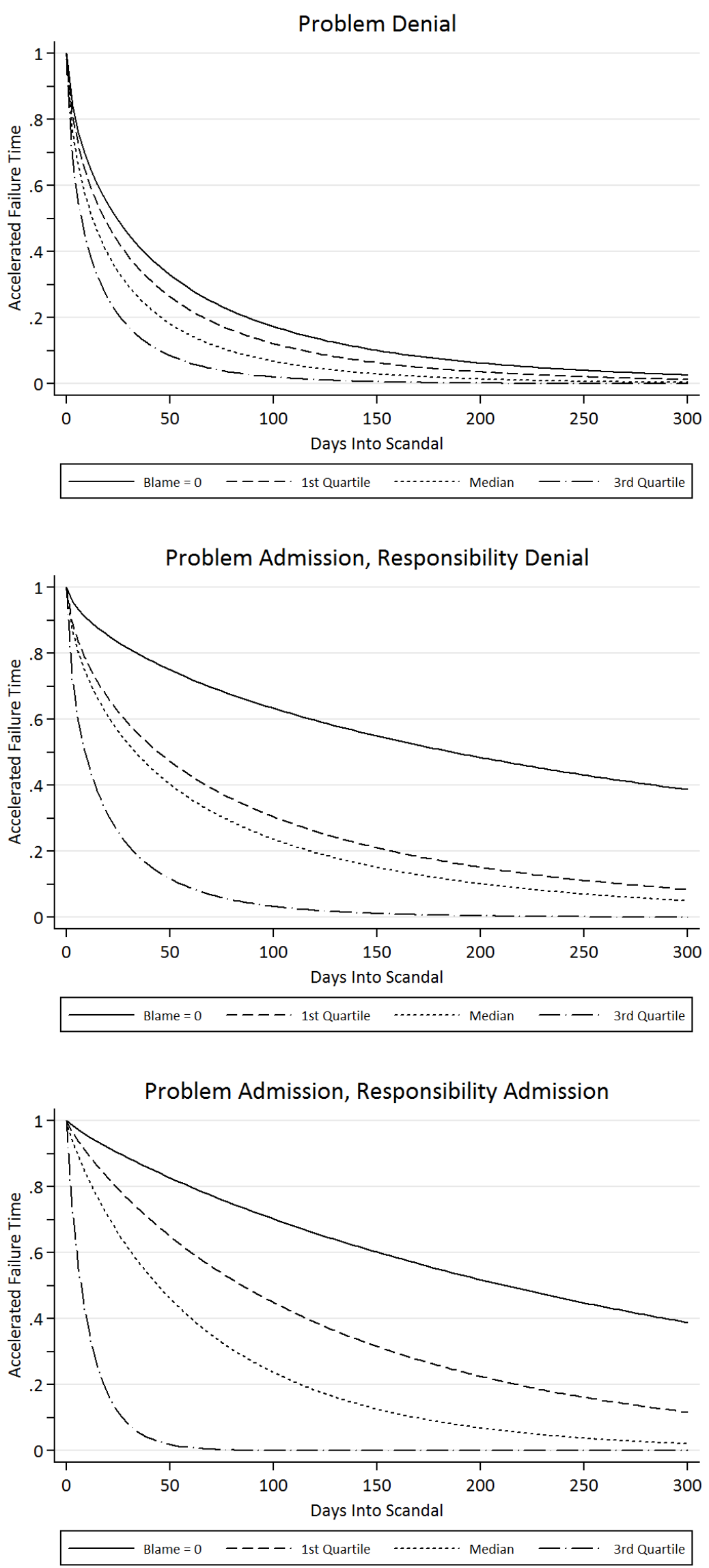
Table 1. The Blame Episodes

\begin{tabular}{|c|c|c|c|c|}
\hline & Ahern & Blair & Clinton & Chrétien \\
\hline Position & Prime Minister & Prime Minister & President & Prime Minister \\
\hline Political System & Unitary-Parliamentary & Unitary-Parliamentary & Federal-Presidential & Federal-Parliamentary \\
\hline Political Party & Fianna Fáil (Centrist) & $\begin{array}{l}\text { Labour Party (Centre- } \\
\text { Left) }\end{array}$ & $\begin{array}{l}\text { Democratic Party } \\
\text { (Centre-Left) }\end{array}$ & Liberal Party (Centre-Left) \\
\hline End & 5 May 2008 & 5 December 1997 & 19 February 1999 & 1 February 2006 \\
\hline Scandal Type & $\begin{array}{l}\text { Personal Loans / } \\
\text { Corruption }\end{array}$ & $\begin{array}{l}\text { Political Donations / } \\
\text { Corruption }\end{array}$ & Sex Scandal / Perjury & $\begin{array}{l}\text { Government Contracts / } \\
\text { Corruption }\end{array}$ \\
\hline Trigger Event & $\begin{array}{l}\text { The Irish Times prints } \\
\text { allegations that Bertie } \\
\text { Ahern, then Minister of } \\
\text { Finance, received large } \\
\text { payments from a } \\
\text { businessman in } 1993 \text {. }\end{array}$ & $\begin{array}{l}\text { The Labour Government } \\
\text { announces proposals for } \\
\text { exemption of Formula } 1 \\
\text { from ban on tobacco } \\
\text { sponsorship, prompting } \\
\text { interest from the media. }\end{array}$ & $\begin{array}{l}\text { Several news } \\
\text { organizations report an } \\
\text { alleged sexual } \\
\text { relationship between } \\
\text { President Clinton and } \\
\text { Monica Lewinsky }\end{array}$ & $\begin{array}{l}\text { Report of the Auditor-General } \\
\text { is published, revealing } \\
\text { payments of up to C } \$ 100 \\
\text { million to Liberal-affiliated } \\
\text { advertising firms and Crown } \\
\text { corporations for minimal work }\end{array}$ \\
\hline
\end{tabular}


Table 2. Summary Statistics

\begin{tabular}{|l|l|l|l|l|}
\hline & Ahern & Blair & Clinton & Chretien \\
\hline Duration of the scandal (days) & 593 & 42 & 394 & 723 \\
\hline Duration until first "PD" Response (days) & 1 & 2 & 0 & 7 \\
\hline Number of newspaper articles (sampled) & 477 & 93 & 775 & 691 \\
\hline $\begin{array}{l}\text { Number of days on which there was an officeholder } \\
\text { response }\end{array}$ & 34 & 5 & 38 & 28 \\
\hline Blame, day & & & & \\
\hline Mean & 1.745 & 0.262 & 2.721 & 1.604 \\
\hline Min & 0 & 0 & 0 & 0 \\
\hline Max & 42 & 32 & 65 & 38 \\
\hline Standard deviation & 4.818 & 7.818 & 5.731 & 4.351 \\
\hline Kurtosis & 30.731 & 6.443 & 48.898 & 28.003 \\
\hline Officeholder responses* & & & \\
\hline None & 559 & 37 & 356 & 695 \\
\hline PD & 33 & 5 & 22 & 3 \\
\hline PA + RD & 0 & 0 & 1 & 20 \\
\hline PA + RA & 1 & 1 & 15 & 5 \\
\hline
\end{tabular}

*It is possible to have multiple responses on a given day, due to multiple articles per day. 
Table 3. Time Series Cross Sectional Model of Reactivity

\begin{tabular}{lc}
\hline \hline & BLAME $_{\mathrm{it}}$ \\
\hline BLAME $_{\mathrm{it}-1}$ & $0.436 * * *$ \\
& $(0.018)$ \\
RESPONSE $_{\mathrm{it}}$ & $8.932 * * *$ \\
& $(0.383)$ \\
$\alpha_{0}$ & $0.578 * * *$ \\
$\mathrm{Adjusted} \mathrm{R}^{2}$ & $(0.092)$ \\
$\mathrm{N}$ & 0.489 \\
$\mathrm{I}$ & 1,748 \\
\hline \hline & 4 \\
\hline
\end{tabular}


Table 4. Parametric Accelerated Failure Rate of Officeholder Responses

\begin{tabular}{|c|c|c|c|c|c|c|c|c|c|}
\hline \multirow[b]{3}{*}{ Var } & \multicolumn{3}{|c|}{ 1.Problem Denial (PD) } & \multicolumn{3}{|c|}{$\begin{array}{l}\text { 2. Problem Admission/Responsibility } \\
\text { Denial (PA + RD) }\end{array}$} & \multicolumn{3}{|c|}{$\begin{array}{l}\text { 3. Problem Admission/Responsibility } \\
\text { Admission (PA + RA) }\end{array}$} \\
\hline & \multirow[b]{2}{*}{$\begin{array}{c}\text { Accelerated } \\
\text { Failure Rate } \\
\text { (S.E.) }\end{array}$} & \multicolumn{2}{|c|}{$\begin{array}{l}\text { 95\% Confidence } \\
\text { Intervals }\end{array}$} & \multirow[b]{2}{*}{$\begin{array}{c}\text { Accelerated } \\
\text { Failure Rate } \\
\text { (S.E.) }\end{array}$} & \multicolumn{2}{|c|}{$\begin{array}{l}\text { 95\% Confidence } \\
\text { Intervals }\end{array}$} & \multirow[b]{2}{*}{$\begin{array}{c}\text { Accelerated } \\
\text { Failure Rate } \\
\text { (S.E.) }\end{array}$} & \multicolumn{2}{|c|}{$\begin{array}{l}\text { 95\% Confidence } \\
\text { Intervals }\end{array}$} \\
\hline & & Lower & Upper & & Lower & Upper & & Lower & Upper \\
\hline Blame & $\begin{array}{c}0.911 * * * \\
(0.016)\end{array}$ & 0.882 & 0.941 & $\begin{array}{r}0.881 * * \\
(0.025)\end{array}$ & 0.833 & 0.932 & $\begin{array}{l}0.872^{* *} \\
(\mathbf{0 . 0 3 4})\end{array}$ & 0.808 & 0.941 \\
\hline Popularity & $\begin{array}{c}0.998 \\
(0.020)\end{array}$ & 0.961 & 1.038 & $\begin{array}{l}1.108 * \\
(0.051)\end{array}$ & 1.011 & 1.213 & $\begin{array}{l}0.957 * \\
(0.020)\end{array}$ & 0.918 & 0.997 \\
\hline Prior PD response & - & & & $\begin{array}{c}7.650 \\
(8.351)\end{array}$ & 0.900 & 64.987 & $\begin{array}{c}0.000 \\
(0.000)\end{array}$ & 0.000 & 0.000 \\
\hline $\begin{array}{l}\text { Prior PD \& PA + } \\
\text { RD response }\end{array}$ & - & & & - & & & $\begin{array}{l}0.150 * \\
(0.132)\end{array}$ & 0.027 & 0.836 \\
\hline $\begin{array}{l}\text { P: distribution } \\
\text { shape parameter }\end{array}$ & $\begin{array}{c}0.659 * * * \\
(0.072)\end{array}$ & 0.533 & 0.816 & $\begin{array}{c}0.759 \\
(0.140)\end{array}$ & 0.529 & 1.088 & $\begin{array}{c}0.885 \\
(0.161)\end{array}$ & 0.620 & 1.265 \\
\hline $\begin{array}{l}\text { Subjects: Number } \\
\text { of Cases }\end{array}$ & 46 & & & 19 & & & 20 & & \\
\hline $\begin{array}{l}\text { Failures: Number } \\
\text { of Officeholder } \\
\text { Responses }\end{array}$ & 42 & & & 15 & & & 16 & & \\
\hline Log Likelihood & -79.051 & & & -26.549 & & & -8.159 & & \\
\hline
\end{tabular}

$* \mathrm{p}<0.05 ; * * \mathrm{p}<0.01 ; * * * \mathrm{p}<0.001$ 
Table 5. Time Series Cross Sectional Model of Efficacy for all Officeholder Responses

\begin{tabular}{lcc}
\hline \hline & \multicolumn{2}{c}{ BLAME $_{\text {it }}$} \\
\hline & All & Personal \\
& Responses & Responses \\
\hline BLAME $_{\mathrm{it}-1}$ & $0.533^{* * *}$ & $0.557^{* * * *}$ \\
& $(0.024)$ & $(0.020)$ \\
RESPONSE $_{\mathrm{it}-1}$ & 0.816 & $-1.752^{* *}$ \\
& $(0.500)$ & $(0.670)$ \\
RESPONSE $_{\mathrm{it}-2}$ & $0.896^{*}$ & $-1.866^{* *}$ \\
& $(0.439)$ & $(0.662)$ \\
$\alpha_{0}$ & 0.794 & 0.803 \\
\hline Adjusted $\mathrm{R}^{2}$ & $(0.105)$ & $(0.104)$ \\
$\mathrm{N}$ & 0.334 & 0.336 \\
I & 1,748 & 1,748 \\
\hline \hline
\end{tabular}

$* \mathrm{p}<0.05 ; * * \mathrm{p}<0.01 ; * * * \mathrm{p}<0.001$ 
Table 6. Time Series Cross Sectional Model of Efficacy for $P A, P A+R D$ and $P A+R A$ Responses

\begin{tabular}{|c|c|c|}
\hline & \multicolumn{2}{|c|}{ BLAME $_{\text {it }}$} \\
\hline & $\begin{array}{c}\text { All } \\
\text { Responses }\end{array}$ & $\begin{array}{l}\text { Personal } \\
\text { Responses }\end{array}$ \\
\hline BLAME $_{\mathrm{it}-1}$ & $\begin{array}{c}0.538 * * * \\
(0.025)\end{array}$ & $\begin{array}{c}0.551 * * * \\
(0.020)\end{array}$ \\
\hline$(\mathrm{PD})_{\mathrm{it}-1}$ & $\begin{array}{l}1.204 * \\
(0.583)\end{array}$ & $\begin{array}{c}0.201 \\
(1.081)\end{array}$ \\
\hline$(\mathrm{PD})_{\mathrm{it}-2}$ & $\begin{array}{c}0.361 \\
(0.555)\end{array}$ & $\begin{array}{c}-2.706^{* *} \\
(1.044)\end{array}$ \\
\hline$(\mathrm{PA}+\mathrm{RD})_{\mathrm{it}-1}$ & $\begin{array}{c}0.347 \\
(1.001)\end{array}$ & $\begin{array}{c}1.164 \\
(1.268)\end{array}$ \\
\hline$(\mathrm{PA}+\mathrm{RD})_{\mathrm{it}-2}$ & $\begin{array}{c}3.059 * * * \\
(0.938)\end{array}$ & $\begin{array}{c}1.591 \\
(1.265)\end{array}$ \\
\hline$(\mathrm{PA}+\mathrm{RA})_{\mathrm{it}-1}$ & $\begin{array}{l}-0.315 \\
(0.974)\end{array}$ & $\begin{array}{c}-6.054 * * * \\
(1.115)\end{array}$ \\
\hline$(\mathrm{PA}+\mathrm{RA})_{\mathrm{it}-2}$ & $\begin{array}{l}-0.035 \\
(0.905)\end{array}$ & $\begin{array}{c}-3.943 * * * \\
(1.124)\end{array}$ \\
\hline$\alpha_{0}$ & $\begin{array}{c}0.793 * * * \\
(0.105)\end{array}$ & $\begin{array}{c}0.811^{* * * *} \\
(0.103)\end{array}$ \\
\hline Adjusted $\mathrm{R}^{2}$ & 0.337 & 0.337 \\
\hline $\mathrm{N}$ & 1,748 & 1,748 \\
\hline I & 4 & 4 \\
\hline
\end{tabular}

$* \mathrm{p}<0.05 ; * * \mathrm{p}<0.01 ; * * * \mathrm{p}<0.001$ 